J. Perinat. Med. 17 (1989) 25

\section{Atrial natriuretic peptide and sodium azide dependent guanylate cyc- lase activities in placentas from normal and severely toxemic patients}

\author{
Christos G. Hatjis and J. D. Bottoms
}

Section on Maternal-Fetal Medicine, Department of Obstetrics and Gynecology, Bowman Gray School of Medicine, Wake Forest University, Winston-Salem, North Carolina, U.S.A.

\section{Introduction}

Particulate guanylate cyclase [9] activity is stimulated by several hormones through membranereceptor mediated effects and by nitrosovasodilators through a direct, receptor independent mechanism. The end result is increased synthesis of intracellular $3^{\prime} 5^{\prime}$-cyclic guanosine monophosphate. The latter is thought to mediate vasodilation. The many and diverse effects of atrial natriuretic peptide (ANP) are brought about through specific plasma membrane ANP receptors, a subtype of which appears to be coupled to particulate guanylate cyclase $[7,8]$. We and others have previously demonstrated the presence of ANP receptors in human placentas $[5,10]$. In a preliminary report, it was shown that these receptors may be coupled to guanylate cyclase activity [11]. We have also presented data suggesting that the affinity of ANP placental receptors for alpha-hANP is decreased in association with severe toxemia of pregnancy [6]. Thus, we have asked the question whether a decrease in the affinity of ANP placental receptors for alpha-hANP is associated with a decrease in ANP-dependent guanylate cyclase activity. To complement the latter, we have also measured receptor-independent enzymatic stimulation by a nitrosovasodilator, sodium azide.

\section{Materials and methods}

\subsection{Patients}

They were randomly selected. Gestational ages ranged from 27-41 weeks. Severe toxemia of pregnancy was defined according to previously published ACOG criteria [1]. All control subjects were normotensive.

\section{Curriculum vitae}

Christos G. Hatus, M.D. was born in Athens, Greece. His B. A. was from Columbia University and his M.D. from the University of Pennsylvania School of Medicine. He did his intership and residency in Obstetrics and Gynecology at the Hospital of the University of Pennsylvania School of Medicine and his

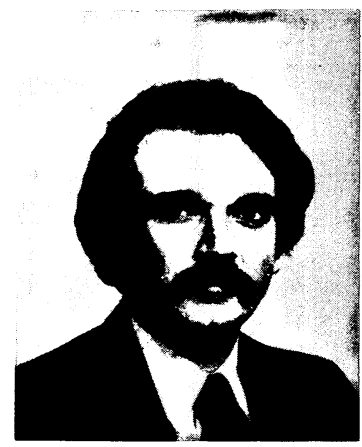

fellowship in Maternal-Fetal Medicine at the University of Vermont School of Medicine. He is Board certified by the American Board of Obstetricians and Gynecologists as well as by its Division of Maternal-Fetal Medicine. He was an Assoicate Professor of Obstetrics and Gynecology at the Wake Forest University Medical Center. Currently, he is the Director of Perinatology at Riverside Methodist Hospitals in Columbus, Ohio. He has authored or coauthored multiple articles. He is a member of many scientific societies including the Society for Gynecologic Investigation and the Society for Perinatal Obstetricians. He is a Fellow of the American College of Obstetricians and Gynecologists. His primary research interests are those in the areas of membrane receptors, cyclic nucleotides and preterm labor.

\subsection{Materials}

Nonradioactive alpha-hANP (124-151) was obtained from Peninsula Laboratories. $\alpha-{ }^{32} \mathrm{P}$-guanosine triphosphate $\left(\alpha-{ }^{32} \mathrm{P}-\mathrm{GTP}, 25 \mathrm{Ci} / \mathrm{mmol}\right)$ and ${ }^{3} \mathrm{H}-3^{\prime} 5^{\prime}$-cyclic guanosine monophosphate $\left({ }^{3} \mathrm{H}\right.$ cGMP, $16 \mathrm{Ci} / \mathrm{mmol}$ ) were obtained from New England Nuclear. The other reagents were obtained commercially and were of the highest purity available. 


\subsection{Tissue}

Human placentas from normal and severely toxemic pregnant patients were obtained at 27-41 weeks gestation immediately following delivery and placed on ice. Fetal membranes and large vessels were then removed by sharp dissection and the placenta was separated into fragments, each one weighing approximately $25-50$ grams. These aliquots were then frozen in liquid nitrogen and stored at $-70^{\circ} \mathrm{C}$ until needed for the assay. Under these conditions, no significant loss in ANP-receptor binding or ANP-dependent guanylate cyclase function was noted with freezing and storage for up to six months.

\subsection{Membrane preparations [5]}

On the day of the assay approximately 5-10 grams of each placenta were allowed to thaw in $45-50 \mathrm{ml}$ of ice-cold, $0.9 \%$ sodium chloride $(\mathrm{NaCl}), 20 \mathrm{mM}$ Tris hydrochloride (Tris- $\mathrm{HCl}), 250$ $\mathrm{mM}$ sucrose, $5 \mathrm{mM}$ ethylenediaminetetraacetic acid (EDTA), $\mathrm{pH}$ 7.5. All subsequent procedures were carried out at $4^{\circ} \mathrm{C}$. The placenta was minced with scissors and subsequently homogenized with a Brinkman polytron on setting \#7, twice, each cycle lasting approximately 30 seconds with a 30 second cooling period between homogenizations. This crude homogenate was filtered through cheesecloth and spun at $40,000 \times \mathrm{g}$ for 15 minutes. The pellet was resuspended and recentrifuged as before, twice. The pellet was resuspended in $0.9 \%$ $\mathrm{NaCl}, 20 \mathrm{mM}$ Tris- $\mathrm{HCl}$ and $5 \mathrm{mM}$ ethylenebis(oxyethylene-nitrilo)tetraacetic acid (EGTA), pH 7.5. The final concentration was approximately $4-10 \mathrm{mg}$ of protein $/ \mathrm{ml}$.

\subsection{Guanylate cyclase assay [4]}

The conversion of $\alpha{ }^{32} \mathrm{P}$-GTP to ${ }^{32} \mathrm{P}-\mathrm{cyclic}-3^{\prime} 5^{\prime}$ GMP was measured in this assay. Aliquots of placental membrane fragments $(350-600 \mu \mathrm{g}$ protein/tube) were incubated at $37^{\circ} \mathrm{C}$ for 10 minutes in an assay buffer that contained the following (final concentrations): 1-methyl-3-isobutyxanthine $(0.75 \mathrm{mM})$, theophylline $(1 \mathrm{mM})$, creatine phosphate $(10 \mathrm{mM})$, creatine phosphokinase $(60 \mu \mathrm{g})$, manganese chloride $(5 \mathrm{mM})$, magnesium chloride $(5 \mathrm{mM})$, guanosine triphosphate $(1 \mathrm{mM}), 3^{\prime} 5^{\prime}-$ cyclic GMP (cGMP) $(0.5 \mathrm{mM})$, and approximately $3-5 \times 10^{6} \mathrm{cpm}$ of $\alpha-{ }^{32} \mathrm{P}-\mathrm{GTP}$. The reaction was stopped with a solution containing sodium dode- cyl sulfate (SDS, $2.5 \%$ ), cyclic GMP (1 mM), GTP (2.5 mM), $20 \mathrm{mM}$ Tris- $\mathrm{HCl}, \mathrm{pH}$ 7.5. ${ }^{3} \mathrm{H}-\mathrm{cGMP}$ (approximately 2,000-3,000 cpm per tube) was added to each tube to monitor the recovery. The suspension was boilded for 5 minutes. Cyclic GMP was isolated by sequential chromatography using Dowex (AG $50 \mathrm{~W}-\mathrm{X} 4$ ) and alumina (WN3-neutral) columns. The recovery ranged from 40$50 \%$. Results have been corrected for recovery.

Basal enzymatic activity was measured in the absence of $\alpha$-hANP or sodium azide $\left(\mathrm{NaN}_{3}\right)$. Stimulation of guanylate cyclase activity was measured in the presence of $\alpha$-hANP $(0.5 \mu \mathrm{m})$ or $\mathrm{NaN}_{3}(100$ $\mu \mathrm{m}) \pm$ catalase.

The amount of protein in the assay was determined by the method of Bradford [3] using bovine serum albumin as the standard. Radioactivity was counted in a scintillation counter. The results are presented as pmol of cyclic GMP generated per milligram of protein per 10 minutes. Statistical analysis is carried out by the Student $t$ test and FisHER's exact probability test. A $p$ value of $<0.05$ is considered as being statistically significant.

\section{Results}

The two groups were comparable with regards to maternal age, gravidity, parity, mode of delivery, and anesthesia (table I). All normal patients were normotensive and showed no proteinuria. In contrast, all toxemic patients were hypertensive (BP $>150 / 100)$ and demonstrated significant proteinuria ( $>4.5 \mathrm{gm} / 24$ hours). In addition, one patient showed thrombocytopenia and elevated liver enzymes. As expected, because of the severity of their disease, toxemic patients were delivered at an earlier point in gestation than the normal patients. Although the Apgar scores were similar in the two groups, there was one neonatal death in the toxemic group due to complications of prematurity. In the antepartum period, toxemic patients had received $\mathrm{MgSO}_{4}$ and hydralazine.

Table II shows guanylate cyclase activity in placentas from normal as well as severely toxemic patients. The results were normalized by log transformation of the data. Raw data were used for calculating the percent increase over basal activity. There was no significant difference with regards to basal guanylate cyclase activity between the two groups. However, stimulation of guanylate cyclase activity by ANP at the maximum concentration 
Table I. Clinical data.

\begin{tabular}{|c|c|c|c|}
\hline Parameters & Normal $(n=4)$ & Toxemics $(n=7)$ & $\mathbf{P}$ \\
\hline Age (years)ף & $26.00 \pm$ & $23.71 \pm$ & NS \\
\hline $\begin{array}{c}\text { Gravidity } \\
1 \\
\geq 2\end{array}$ & $\begin{array}{l}1 \\
3\end{array}$ & $\begin{array}{l}4 \\
3\end{array}$ & NS \\
\hline $\begin{array}{r}\text { Parity } \\
0 \\
\geq 1\end{array}$ & $\begin{array}{l}1 \\
3\end{array}$ & $\begin{array}{l}6 \\
1\end{array}$ & NS \\
\hline $\begin{array}{l}\text { Mode of delivery } \\
\text { Vaginal } \\
\text { C-section }\end{array}$ & $\begin{array}{l}2 \\
2\end{array}$ & $\begin{array}{l}3 \\
4\end{array}$ & NS \\
\hline $\begin{array}{l}\text { Anesthesia } \\
\text { Conduction } \\
\text { General }\end{array}$ & $\begin{array}{l}3 \\
1\end{array}$ & $\begin{array}{l}5 \\
2\end{array}$ & NS \\
\hline Gestational age (weeks) & $39.75 \pm 1.26$ & $31.71 \pm 2.56$ & 0.0003 \\
\hline NNBW (gm)ף & $3197.25 \pm 564.91$ & $1500.29 \pm 492.36$ & 0.0006 \\
\hline $\begin{array}{l}\text { Apgar score at } 5 \mathrm{~min} \\
\quad \leq 6 \\
\geq 7\end{array}$ & $\begin{array}{l}0 \\
4\end{array}$ & $\begin{array}{l}2 \\
5\end{array}$ & NS \\
\hline Hemoglobin (gm\%) I & $11.37 \pm \quad 0.78$ & $12.30 \pm$ & NS \\
\hline Proteinuria (mg/24 hours) ๆ & NEG & $11706.67 \pm 6967.51(n=6)$ & -- \\
\hline Creatinine clearance $(\mathrm{cc} / \mathrm{min}) \uparrow$ & NA & $117.50 \pm 24.68(n=6)$ & -- \\
\hline
\end{tabular}

Tा Mean \pm S.D.; NNBW: neonatal birth weight

Table II. ANP-Dependent guanylate cylase activity.

\begin{tabular}{llll}
\hline & \multicolumn{1}{l}{$[\log (\mathrm{pmol} / \mathrm{mg}$ protein/min) $]$} & \\
\cline { 2 - 4 } & Basal & $\alpha$-hANP $(0.5 \mu \mathrm{M})$ & $\begin{array}{c}\text { \% Increase over } \\
\text { Basal activity }\end{array}$ \\
\hline Normal $(\mathrm{n}=4)$ & $2.231 \pm 0.703$ & $2.942 \pm 0.644$ & $104.81 \pm 12.02^{*}$ \\
Toxemia $(\mathrm{n}=7)$ & $1.955 \pm 0.196$ & $2.345 \pm 0.232$ & $49.41 \pm 8.73^{*}$ \\
\hline
\end{tabular}

I Mean \pm SEM, $(n)=$ number of patients

$* \mathrm{p}<0.005$

of ANP studied $(0.5 \mu \mathrm{M})$ was higher in normal than in toxemic placentas. The percent increase of enzymatic activity compared to basal was significantly higher in placentas from normal patients than from severely toxemic patients.

We next measured stimulation of guanylate cyclase activity by a nitrovasodilator. We used sodium azide $\left(\mathrm{NaN}_{3}\right)$, with or without catalase. In some tissues, catalase has been found to be a necessary co-factor for $\mathrm{NaN}_{3}$-induced guanylate cyclase stimulation [9]. Guanylate cyclase was stimulated by $\mathrm{NaN}_{3}$ but exhibited a higher degree of activity in the presence of catalase in both groups of patients (table III). The percent stimulation over basal enzymatic activity was significantly higher in placentas from normal than in those from severely toxemic patients. 
Table III. $\mathrm{NaN}_{3}$-Induced guanylate cyclase activity.

\begin{tabular}{llcc}
\hline & \multicolumn{2}{l}{$[\log (\mathrm{pmol} / \mathrm{mg}$ protein/min)] } & \\
\cline { 2 - 4 } & Basal & $\mathrm{NaN}_{3}(\%) \S$ & $\begin{array}{l}\mathrm{NaN}_{3}+ \\
\text { Catalase }(\%) \S\end{array}$ \\
\hline Normal $(\mathrm{n}=4)$ & $2.231 \pm 0.703$ & $2.675 \pm 0.683$ & $3.319 \pm 0.763$ \\
& & $(58.401 \pm 16.702)^{*}$ & $(198.946 \pm 19.864)^{* *}$ \\
Toxemia $(\mathrm{n}=7)$ & $1.955 \pm 0.196$ & $2.082 \pm 0.229$ & $2.606 \pm 0.276$ \\
& & $(16.260 \pm 10.594)^{*}$ & $(102.110 \pm 28.042)^{* *}$ \\
\hline
\end{tabular}

T Mean $\pm \operatorname{SEM} ;(n)=$ number of patients

$\S(\%)=\%$ increase over basal activity

$* \mathrm{p}=0.048$

$* * \mathrm{p}=0.041$

\section{Discussion}

In these experiments we have demonstrated that there is an ANP-dependent guanylate cyclase activity in placentas obtained both from normal and severly toxemic patients. Moreover, we have shown that although the basal activities are similar, the percent increase in ANP-dependent guanylate cyclase activity is lower in toxemic placentas than in placentas from normal women at term. Finally, the percent increase in nitrovasodilatorinduced $\left(\mathrm{NaN}_{3}\right)$ placental guanylate cyclase activity was also lower in toxemic than in normal patients.

Guanylate cyclase is thought to be involved in regulating vascular tone [9]. Stimulation of this enzyme results in intra-cellular release of cyclic GMP. The latter is thought to mediate vasodilation. Several hormones, including ANP, stimulate guanylate cyclase through binding to specific membrane receptors. Another class of compounds, the so-called nitrosovasodilators, stimulate this enzyme directly via a nitric oxide dependent mechanism. In either case, production of cGMP is presumed to induce phosphorylation of similar or identical substrates that ultimately mediate vasodilation.

The role of cGMP in terms of placental hemodynamics has not been adequately investigated. Basal guanylate cyclase activity may not necessarily reflect the functional properties of the tissue. Thus, we chose to examine this enzymatic activity in a more dynamic fashion, i.e. stimulated activity. Our observation that the stimulated cyclase activity is reduced in placentas from toxemic patients suggests that there might be an association be- tween certain aspects of placental hemodynamic regulation and guanylate cyclase activity. While ANP appears to be an important factor in terms of guanylate cyclase stimulation in placental plasma membranes, it is by no means the only factor that may influence its overall function. This is supported by our results concerning $\mathrm{NaN}_{3}$-dependent enzymatic activity. However, in placentas for severely toxemic patients, the percent stimulation of guanylate cyclase activity is decreased both in the case of ANP as well as in the case of a nitrosovasodilator, $\mathrm{NaN}_{3}$.

ANP effects are mediated through specific plasma ANP receptors. One subtype of these receptors is coupled to guanylate cyclase $[7,8]$. A second subtype of ANP receptor has been shown to mediate its effects independent of guanylate cyclase [7]. However, in the latter case, the nature of the second messenger is not known. Although guanylate caclase is found both in the plasma membrane as well as in cytoplasmic fractions, as these experiments suggest and as we have previously discussed, placental ANP receptors are presumed to be located in a microsomal plasma membrane fraction which is thought to be exposed primarily to fetal blood [5].

While these observations support our previously reported results on placental ANP binding characteristics [6], they cannot answer the question whether they represent a primary or secondary event in patients with toxemia of pregnancy. Other confounding variables, such as gestational age, maternal treatment with $\mathrm{MgSO}_{4}$ or antihypertensive agents, might have influenced the results. Finally, there are conflicting reports $[2,12,13]$ with 
regards to maternal plasma ANP concentrations in toxemia of pregnancy. Whereas some investigators have reported them to be higher than in normals [2, 13], others have not been able to confirm those results [2]. It is not known whether fetal ANP levels are altered in toxemia of pregnancy. Further experiments need to be designed to answer these specific questions.

\section{Abstract}

Particulate guanylate cyclase is stimulated by several hormones through receptor-dependent and by nitrosovasodilators through receptor-independent mechanisms. A subtype of atrial natriuretic peptide (ANP) receptors is coupled to guanylate cyclase. It has been shown that there is a down-regulation of the affinity of ANP receptors to $\alpha$-hANP in placental plasma membranes obtained from severely toxemic patients. We have asked the question whether these changes are associated with a downregulation of ANP-dependent guanylate cyclase activity. Guanylate cyclase was determined by in vitro experiments using a placental plasma membrane fraction obtained from normal and from severely toxemic patients. The presence of ANP-dependent placental guanylate
\end{abstract}

cyclase activity was demonstrated both in normal and toxemic placentas. Although basal guanylate cyclase activity was not influenced by toxemia of pregnancy, there was a significant decrease in the maximum stimulation of this enzyme by $\alpha$-hANP $(104.81 \pm 12.02 \%(n=4)$ vs $49.41 \pm 8.73 \%(n=7)$ for normal and toxemics, respectively). Finally, stimulation by a nitrosovasodilator, sodium azide $\left(\mathrm{NaN}_{3}\right)$, was also lower in toxemic placentas than in normal controls. These observations extend our previously reported results on placental ANP receptor function but also suggest the presence of a possibly receptor-independent decrease in guanylate cyclase activity in toxemic placentas.

Keywords: ANP, Guanylate cyclase activity, human placenta, $\mathrm{NaN}_{3}$, toxemia of pregnancy.

\section{Zusammenfassung}

Atriale natriuretische Paptide und die Aktivität von $\mathrm{NaN}_{3}-$ abhängigen Guanylatcyclasen in Plazenten von gesunden und schwer toxikotischen Patientinnen

Speziell die Guanylatcyclase wird rezeptorabhängig durch verschiedene Hormone und rezeptorunabhängig durch Nitroso-Vasodilatatoren stimuliert. Das atriale natriuretische Peptid (ANP) ist ein Hormon, dessen Sekretion durch Muskelzellen im Vorhof über einen ansteigenden intraartrialen Druck und über eine Zunahme der Vorhofdehnung gesteuert wird. Die Wirkungen des ANP werden über spezifische Plasmamembranrezeptoren vermittelt. Ein Subtyp der ANP-Rezeptoren ist an die Guanylatcyclase gekoppelt. Es konnte gezeigt werden, da $\beta$ in plazentaren Plasmamembranen von schwer toxikotischen Patientinnen die Affinität der ANP-Rezeptoren für $\alpha$-hANP abnimmt. Unsere Fragestellung war, ob diese Veränderungen mit einer Verminderung der ANP-abhängigen Guanylatcyclase-Aktivität assoziiert sind. Durch in vitro-Experimente erhielten wir Guanylatcyclase aus plazentaren Plasmamembranfraktionen von gesunden und schwer toxikotischen Patientinnen. Die Konversion von $\alpha^{-32}$-P-GTP zu cyclischem ${ }^{32}$ P-GMP wurde basal sowie nach Stimulation gemessen. Das cyclische GMP wurde durch Sequenzchromatografie isoliert und dann quantifiziert. Es erfolgten Korrekturen für die prozentuale Wiederfindungsrate und den Proteingehalt. Sowohl in normalen wie in toxikotischen Plazenten war eine ANP-abhängige Guanylatcyclase-Aktivität nachweisbar. Obwohl die basale Guanylatcyclase-Aktivität (ausgedrückt als log-pmol/mg Protein/min) nicht durch eine Toxikose in der Schwangerschaft beeinflußt war (normal: $2.231 \pm 0.703, \mathrm{n}=4$; toxikotische: 1.955 $\pm 0.196, n=7)$ zeigte sich ein signifikanter Abfall in der prozentualen Stimulation dieses Enzyms durch $\alpha$ hANP (normal: $104.81 \pm 12.02 \%$, toxikotisch: 49.41 $\pm 8.73 \%$ ). Schließlich war die prozentuale Stimulation durch einen Vasodilatator, $\mathrm{NaN}_{3}$, in toxikotischen Plazenten auch geringer als bei den Kontrollen (102.11 $\pm 28.04 \%$ vs. $198.95 \pm 19.86 \%$ ). Man nimmt an, daß die Guanylatcyclase bei der Regulation des vaskulären Tonus beteiligt ist. Eine Stimulation dieses Enzyms bewirkt eine intrazelluläre Freigabe von cyclischem GMP, das die Vasodilatation induzieren kann. Die Funktion des cGMP bei der plazentaren Hämodynamik wurde bisher noch nicht ausreichend untersucht. Unsere Beobachtungen weisen darauf hin, daß ein möglicher $\mathrm{Zu}$ sammenhang zwischen der hämodynamischen Regulation der Plazenta und der Guanylatcyclase-Aktivität besteht. Wenn auch das ANP ein wichtiger Faktor bei der Guanylatcyclase-Stimulation in Plazentamembranen ist, so handelt es sich keinesfalls um den einzigen Faktor bei der Beeinflussung der Gesamtfunktion. Dies zeigen auch unsere Ergebnisse mit der $\mathrm{NaN}_{3}$-abhängigen Enzymaktivität. Auf jeden Fall ist die Enzymstimulation sowohl beim ANP wie auch beim Nitroso-Vasodilatator $\mathrm{NaN}_{3}$ gesenkt. Diese Beobachtungen unterstützen unsere bereits veröffentlichten Ergebnisse hinsichtlich der Abnahme der Affinität des plazentaren ANP-Rezeptors für $\alpha$-hANP bei Toxikosen. Wir können jedoch nicht die Frage beantworten, ob damit bei Patientinnen mit Schwangerschaftstoxikosen eine Ursache oder ein Folgezustand beschrieben wird. Weitere Untersuchungen sind notwendig, um diese spezifischen Fragen zu klären.

Schlüsselwörter: ANP, Guanylatcyclase-Aktivität, $\mathrm{NaN}_{3}$, Plazenta beim Menschen, Schwangerschaftstoxikose. 


\section{Résumé}

Peptide atrial natriurétique et activité guanylate cyclase sodium azide dependante au niveau de placentas provenant de patientes normales et avec toxemie sevère

La guanylatecyclase est stimulée par plusieurs hormones selon des mécanismes récepteurs dépendants et par des nitrosovasodilateurs selon des mécanismes non récepteurs dépendants. Le peptide atrial natriurétique (ANP) est une hormone dont la secretion par les intra-atriale et de la tension atriale. Les effets induits par l'ANP s'exercent par l'intermédiare de récepteurs membranaires spécifiques. Un sous type de récepteur ANP est couplé à la guanylate cyclase. Il a été montré qu'il existe une diminution de l'affinité des récepteurs ANP pour l' $\alpha-h$ ANP dans les membranes du plasma placentaire en provenance de patientes atteintes de toxémie sévère. Nous nous sommes demandés si ces modifications s'accompagnent d'un freinage de l'activité guanylate cyclase ANP dépendante. La guanylate cyclase a été étudiée par des expériences in vitro en utilisant des fractions de membrane du plasma placentaire provenant de patientes normales et atteintes de toxémie sévère. On a mesuré la conversion de l' $\alpha 32$ P.GTP en 32 P.GMP cyclique à l'état basal et après stimulation. Le GMP cyclique a été isolé par chromatographie séquentielle. Le receuil á été surveillé. Les résultats ont été corrigés en pourcent de receuil et en quantité de protéine. On a démontré la présence d'activité guanylate cyclase placentaire AND. dépendante dans les placentas normaux et dans les placentas de toxémiques. Bien que l'activité guanylate cyclase de base exprimée en $\log (\mathrm{pmol} / \mathrm{mg}$ de protéine/min) ne soit pas influencée par la toxémie gravidique (normal $=2,231 \pm 0,703(n=4)$; toxémie: $1,955 \pm 0,196 ; n=7$ ) il y a une diminution significative de la stimulation de cette enzyme par l' $\alpha$-hANE $(104,81$ $\pm 12,02$ versus $49,41 \pm 8,73 \%$ respectivement pour la normale et la toxémie). La stimulation par un nitrosovasodilatateur, le sodium azide, est également plus faible dans les placentas de toxémiques que dans les placentas témoins normaux $(102,11 \pm 28,04 \%$ VS 198,95 $\pm 19,86 \%)$. On pense que la guanylate cyclase est impliquée dans la régulation du tonus vasculaire. La stimulation de cette enzyme entraine une libération intracellulaire de GMP cyclique qui peut induire une vasodilatation. Le rôle du CGMP en terme d'hémodynamique placentaire n'a pas été exploré de façon adéquate. Les observations que nous présentons suggèrent qu'il pourrait y avoir une relation entre certains aspects de la régulation de l'hémodynamique placentaire et l'activité guanylate cyclase. Bien que l'ANP semble être un facteur important en ce qui concerne la stimulation de la gyanylate cyclase dans les membranes du plasma placentaire, ce n'est sûrement pas l'unique facteur qui peut influencer sa fonction globale. Nos résultats concernant l'activité enzymatique sodium azide dépendante renforce cette opinion. Néanmoins, la stimulation de l'enzyme diminue avec l'ANP aussi bien qu'avec le sodium azide', nitrosovasodilatateur. Ces observations renforcent la diminution de l'affinité pour l' $\alpha$-hANP des récepteurs ANP placentaires chez les toxémiques que nous avions antérieurement rapportée. Toutefois, les observations ne permettent pas de répondre à la question de savoir si cette diminution est primitive ou secondaire chez les patientes ayant une toxémie gravidique. D'autres expériences sont nécessaires pour répondre à ces questions spécifiques.

Mots-clés: Activité guanylate cyclase, ANP, NaN3, placenta humain, toxémie gravidique.

Comment: This work was partially presented at the 35th Annual Meeting of the Society for Gynecologic Investigation in Baltimore, Maryland, 1988.

\section{References}

[1] ACOG Technical Bulletin. Management of preeclampsia. No. 91 (1986)

[2] Bond A, P Taufield, M Druzin, S Atlas, J SEALEY, J LARAGH: Atrial natriuretic factor and renin levels in normal and hypertensive pregnancy. Abstract \# 294 presented at the 35th Annual Meeting of the Society for Gynecologic Investigation, March, 1988

(3] BRADFORD MM: A rapid and sensitive method for the quantitation of microgram quantities of protein utilizing the principle of protein-dye binding. Anal Biochem 72 (1976) 248
[4] Field M, LH GRaf JR, WJ LaIRD, PL SMith: Heatstable entero-toxin of Escherichia coli: in vitro effects on guanylate cyclase activity, cyclic GMP concentration, and ion transport in small intestine. Proc Natl Acad Sci 75 (1978) 2800

[5] HATJIS CG, DM GROGAN: Atrial natriuretic peptide receptors (ANP) in normal human placentas. Am J Obstet Gynecol. 159 (1988) 587

[6] HatjIS CG, DM GrogaN: Atrial natriuretic peptide (ANP) receptors in human placentas from normal and severely toxemic patients. Abstract \#295 presented at the 35th Annual Meeting of the Society for Gynecologic Investigation, March, 1988 
[7] JACOBS JW, GP VlasuK, M Rosenblatt: Atrial natriuretic factor receptors. Endocrinol Metab Clinics North America 16 (1987) 63

[8] LeITMaN DC, F MURAD: Atrial natriuretic factor receptor heterogeneity and stimulation of particulate guanylate cyclase and cyclic GMP accumulation. Endocrinol Metab Clinics North America 16 (1987) 79

[9] RAPAPORT RM, F MURAD: Endothelium-dependent and nitrovaso-dilator-induced relaxation of vascular smooth muscle: role of cyclic GMP. J Cyclic Nucleotide Protein Phosphorylation Res 9 (1983) 281

[10] SEN I: Identification and solubilization of atrial natriuretic factor receptors in human placenta. Biochem Biophys Res Comm 135 (1986) 480

[11] SEN I, P Roy: Atrial natriuretic factor induced phosphorylation of human placental membrane protein: an effect mimicked by guanosine $3^{\prime}: 5^{\prime}$-cyclic monophosphate. Biochem Biophys Res Comm 139 (1986) 431
[12] Senyei A, B Koperek, M Pandian, M Porto: Atrial natriuretic factor in PIH: a potential biochemical roll over test. Abstract \#255 presented at the Eighth Annual Meeting of the Society of Perinatal Obstetricians, February, 1988

[13] Thomsen JK, TL Storm, G Thamsborg, M De Nully, B BoDKer, S SKouby: Atrial natriuretic peptide concentrations in pre-eclampsia. $\mathrm{Br}$ Med J 294 (1987) 1508

Received September 20, 1988. Accepted October 20, 1988.

Christos G. Hatjis, M. D.

Director of Perinatology

Riverside Methodist Hospitals

3535 Olentangy River Road

Columbus, Ohio 43214

U.S.A. 